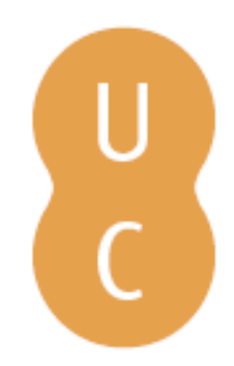

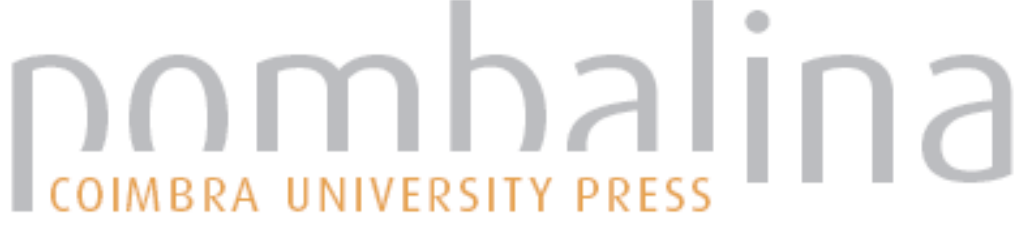

\section{Hera Eleutheria, the water of freedom and the slaves}

Autor(es): Rocca, Francesca

Publicado por: Imprensa da Universidade de Coimbra

URL

persistente: URI:http://hdl.handle.net/10316.2/44717

DOI: $\quad$ DOl:https://doi.org/10.14195/978-989-26-1564-6_2

Accessed : $\quad$ 26-Apr-2023 01:02:26

A navegação consulta e descarregamento dos títulos inseridos nas Bibliotecas Digitais UC Digitalis, UC Pombalina e UC Impactum, pressupõem a aceitação plena e sem reservas dos Termos e Condições de Uso destas Bibliotecas Digitais, disponíveis em https://digitalis.uc.pt/pt-pt/termos.

Conforme exposto nos referidos Termos e Condições de Uso, o descarregamento de títulos de acesso restrito requer uma licença válida de autorização devendo o utilizador aceder ao(s) documento(s) a partir de um endereço de IP da instituição detentora da supramencionada licença.

Ao utilizador é apenas permitido o descarregamento para uso pessoal, pelo que o emprego do(s) título(s) descarregado(s) para outro fim, designadamente comercial, carece de autorização do respetivo autor ou editor da obra.

Na medida em que todas as obras da UC Digitalis se encontram protegidas pelo Código do Direito de Autor e Direitos Conexos e demais legislação aplicável, toda a cópia, parcial ou total, deste documento, nos casos em que é legalmente admitida, deverá conter ou fazer-se acompanhar por este aviso.

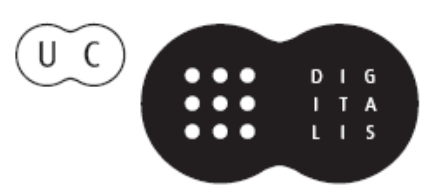




\section{História Antiga:}

Relações

Interdisciplinares.

Fontes, Artes, Filosofia,

Política, Religião e Receção

\section{Carmen Soares, José Luís Brandão \& Pedro C. Carvalho (coords.)}




\title{
Hera Eleutheria, the Water of freedom and the slaves
}

\author{
Francesca Rocca (francina.r@libero.it) \\ Assegnista di Ricerca -Università degli Studi di Torino
}

\begin{abstract}
Aвstract - In the Greek colony of Kroton the goddess Hera was worshipped with the epithet Eleutheria, which can be translated as "grantor of freedom". Her cult was in fact possibly connected with the protection and the manumission of slaves, as the epigraphic and archaeological data seem to suggest. Some inscriptions (all considered in the text) that possibly concern the manumission of slaves or their consecration to the goddess were discovered in the renowned temple of Capo Lacinio. This reminds us the role of asylum that the sanctuary used to have. The Heraia of Argos and Samos were also places where the slaves, as suppliants, could seek refuge. Some wrist and foot chains broken with a mallet were found in the smaller temple (Heraion) of Vigna Nuova and these items may refer to some prisoners, who were set free all together. Finally, the adjective eleutherios/eleutheros appears to be strongly related with water and the ritual connected to it (drinking, immerging) to be released from slavery.

KEYwords - slavery; manumission inscriptions; ritual of manumission; cult of Hera, sanctuary of Capo Colonna.
\end{abstract}

The literary and epigraphic sources concerning the manumission of slaves in Greece have been pretty well known since the end of the nineteenth century. Many of the conclusions, suggested by Drachman in his book, De manumissione servorum apud Graecos, quale ex inscriptionibus cognoscimus, are still relevant. Moreover, although in certain respects outdated, the monographic study $\mathrm{La}$ manomissione e la condizione dei liberti in Grecia, published by Calderini in 1908, has remained, thus far, one of the best treatments of the topic. It is apparent that the dossier of documents known at the very beginning of the last century has needed an update from time to time, since year after year, in archaeological excavations, hundreds of new inscriptions were - and still are - brought to light ${ }^{1}$. The number of the stelae has significantly increased and the literary sources

1 The following works may be considered the essential bibliography about Greek manumission: first and foremost Drachmann 1878 and Calderini 1908, which I have already mentioned in the text; Bömer 1960; Rädle 1969; Albrecht 1978; Klees 1998 and Id. 2000; Darmezin 1999; Zelnick-Abramovitz 2005 and now also Ead. 2013, with a special attention to the manumission acts from Thessaly; see also Kamen 2005 (unpublished) and Kamen 2013, 32-42 (chap. 3). See also Kranzlein 1983; Velissaropoulos-Karakostas 2011, 343-452. One might also note an interesting online corpus of manumission inscriptions: www. iath.virginia. edu/meyer. The leader of the project, Elisabeth Meyer, has recently published a book about inscriptions (mainly manumissions) from Dodona (see Meyer 2013). 
have been systematically reconsidered by the scholars. Therefore, the book of Zelnick-Abramovitz, Not Wholly Free. The Concept of Manumission and the Status of Manumitted Slaves in the Ancient Greek World, published in 2005, has been essential and well received.

At present, many scholars (epigraphists, historians and jurists) are dealing with the sources concerning manumission and, above all, the freedman's status. The bibliography is growing faster; the congresses about slavery and the ways out of it are increasing in number. But I must say, quite surprisingly, that in the great majority of the essays that I have read and papers heard, the inscriptions and the archaeological data found in the South of Italy - namely in Magna Graecia - are not mentioned ${ }^{2}$. And this becomes even stranger if we think that, especially in Sicily and Calabria, we have very early proofs of the existence of freedmen and, as a consequence, of manumission ${ }^{3}$. So, in spite of the surprising lack of attention in these sources, I would like to focus on a group of documents, found in a specific sanctuary of the south of Italy, that is to say, the Temple of Hera Lacinia, located at Capo Colonna, near Kroton, to see if they can reveal to us something unique and perhaps thereby improve our knowledge of the topic.

\section{The sanctuary of Hera at Capo Colonna}

The importance of the archaeological site of Capo Colonna primarily lies in the historical elements linked to the sanctuary, which was dedicated to Hera Lacinia. The sacred area was established near (but not quite so near) the ancient Achaean colony of Kroton ${ }^{4}$. This polis was itself founded by the Achaeans, led by the oikist Myskellos of Rhypai, in the last decades of the $8^{\text {th }}$ century, most likely after Sybaris, which was established in $720 \mathrm{BC}^{5}$. The

${ }^{2}$ A complete corpus of all the sources related to manumission in the South of Italy is not available, as far as I know. A useful (but now not totally updated) bibliographic review is given by Cordiano 2000: 116 .

${ }^{3}$ A very early instance of the word exeleutheros appears on a ceramic fragment which can be dated in the $6^{\text {th }}$ century BC. The fragment was found in Leontini, Sicily, and consists of a dedication made by a manumitted man, namely an exeleutheros (see Manganaro 2004: 55-68 and especially 63). The other early data linked with manumission were found in the sanctuary of Capo Colonna -Kroton- and will be considered in the text.

${ }^{4}$ The collection of essays published by Spadea 2014 is the more recent and exhaustive study on the Achaean polis of Kroton. Nonetheless, it is worth noting the congress that was dedicated to the Greek polis of Kroton in 1983 (Crotone 1983 in bibliography). An update of the findings and studies was undertaken in 1993, when another conference was held at the University of Naples (see Crotone 1993). Another very useful review of the materials was the congress which took place in 2000 at Kroton (see Belli Pasqua - Spadea 2005 in bibliography). On the history of the city, see also Giangiulio 1989.

5 The date of the foundation of Sybaris is suggested by Ps.-Scymn. 337-360. We have a rich and quite tangled documentation about the foundation of Kroton, which took place after many Delphic oracular responses (Zen. 3. 42 = Hippys, FrGrHist 1; Str. 6.1.12= Antiochus 
Heraion of Capo Colonna was probably built in the same place where some preexistent indigenous cult was already worshipped. In any case, the archaeological finds only start to become copious from the $7^{\text {th }}$ century onwards ${ }^{6}$. The buildings and the materials attest that in the classical period the temple was very well known. The dedications offered by the devotees are precious and rich and testify to a certain internationality of the sanctuary, that was still flourishing in Roman times. In 194 BC, on the promontory, the Roman Colony of Croto was founded: the houses and structures were brought to light during the excavations carried on from the end of the last century until the very beginning of this new millennium ${ }^{7}$. We must underline that, even if the domestic area of the colonia was placed on the cape, the sacred space and the main temple were respected and no secular buildings were built on the pre-existing structures. Unfortunately, the same statement does not work for the recent centuries, when unauthorized houses have been built very near the archaeological site, which, in addition, has been used as a stone quarry (with precious and already cut marbles available $)^{8}$.

The sanctuary, as Livy says, was $25 \mathrm{Km}$ from Kroton (now only $13 \mathrm{Km}$ to modern Crotone) and was consecrated to Hera, called Lacinia, by the name of the promontory, which stands above the Ionic sea ${ }^{9}$. Hera used to protect the wild nature (the sanctuary was in a place characterized by growing and luxuriant

of Syracuse, FrGrHist 12 and D. S. 8. 17). We know for sure, already from Herodotus (8. 47), that the two colonies (Sybaris and Kroton) were Achaean. The three aforementioned sources concerning the ktisis of the polis report that the colony of Sybaris was already settled when Kroton was to be founded. Dionysius of Halicarnassus (2. 59. 3) suggests 709-708 BC as a date for the settlement of the Greek colony; Eusebius (91b Helm) offers 704-703 BC. Another tradition links the foundation of Kroton with the colony of Syracuse (Str. 6. 2. 4). The precise date, therefore, is not really sure. See, inter alios, Berard 1963: 152-161; Mele 1983: 42; Giangiulio 1989: 134; Lombardo 2011: 25-26.

${ }^{6}$ The excavations on Capo Colonna have a quite long story, which has been presented and summarized by Spadea on many occasions; see Spadea 2006a: 14-29; Id. 2006b: 264-272; Id. 2009: 63-90. It is quite interesting, therefore, to discover how the materials were brought to light. For the catalogue of the findings see Spadea 1996 and 2006c, 45-46. See also Guzzo 2014, 509-517. About the different chronological phases of the sanctuary see Spadea 1996, 33-50; Id. 1997, 235-259; see also Aversa 2006, 31-49.

7 The main sources is Livy (34. 45. 4-5). About the archeological excavations, see Spadea 2006a: 51-65 and Id. 2009: 82-84.

${ }^{8}$ On that point, see Spadea 2009: 64-67.

${ }^{9}$ Liv. 24. 3. 3. 8. I would like to quote the whole relevant passage: sex milia aberat ab urbe nobile templum ipsa urbe nobilius Laciniae Iunonis, sanctum omnibus circa populis. Lucus ibi frequenti silva et proceris abietis arboribus saeptus laeta in medio pascua habuit, ubi omnis generis sacrum deae pecus pascebatur sine ullo pastore; separatimque greges sui cuiusque generis nocte remeabant ad tabula numquam insidiis ferarum, non fraude violati hominum. Magni igitur fructus ex eo pecore capti, columnaque inde aurea solida facta et sacrata est; incytumque templum divitiis etiam, non tantum sanctitate fuit. Ac miracela aliqua adfingunt, ut plerumque tam insignibus locis. Fama est aram esse in vestibolo templi, cuius cinerem nullo umquam moveat ventus. 
vegetation) and, of course, the sailors. In fact, the cape with the columns of the temple on the top was visible from the sea, also from a distance. In the sanctuary, Hera was worshipped under different epikleseis, which corresponded to the different features she could manifest. The goddess was described as Kourotrophos and Hoplosmia, that is to say that she was linked with maternity, fertility, but also with war and weapons ${ }^{10}$.

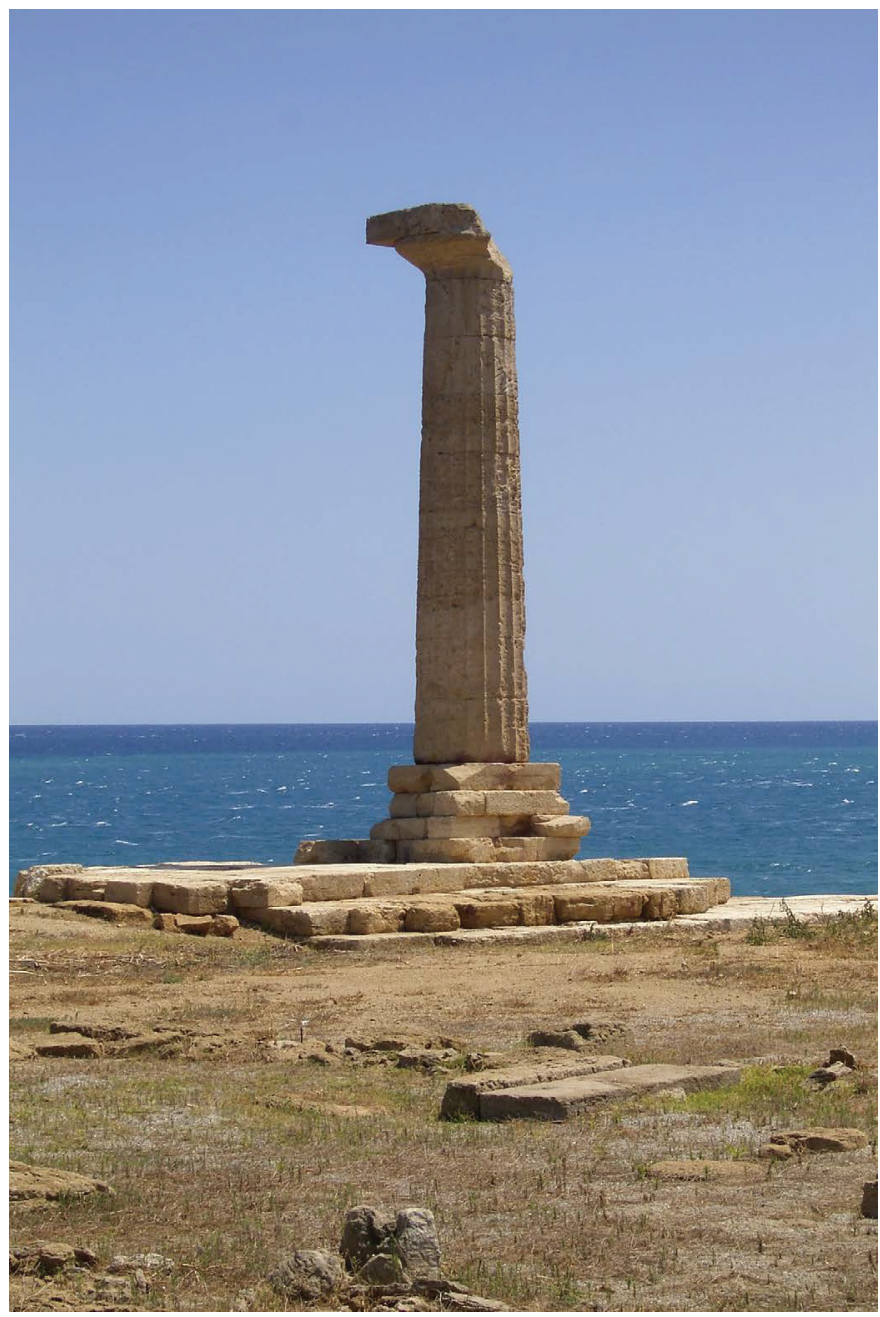

Picture 1. The surviving column of the Heraion (temple A). Picture taken by the author, in August 2005.

${ }^{10}$ On the main features of Hera, see Mele 1996: 235-240; the main sources are quoted here. For a very complete treatment of the cult of Hera, see La Genière 1997 (ed). See also Belli Pasqua 2006: 37-39. 
Another epithet she had was Eleutheria, which concerns us closely, since it is attested in several intriguing inscriptions, that I would like to consider in the following pages.

\section{The InSCRIPTIONS RELATED to Hera EleUtheria}

\subsection{Sandstone block with dedication to Hera Eleutheria}

The first document attesting the epithet Eleutheria referring to Hera is a sandstone block, found in the eastern area of the classical temple, which was the main building of the sanctuary area, under the only surviving column ${ }^{11}$. It is now on display at the new museum, built in the archaeological area on the cape in 2006. The artifact - and this must be underscored - is complete on all sides. It is $35 \mathrm{~cm}$ high and around $30 \mathrm{~cm}$ wide. The letters are not so big, around $4 \mathrm{~cm}$, and they are clearly archaic, written in the Achaean alphabet (the sibilant is san, at the end of the first line; one may also note the three-bar iota, which is diagnostic; the aspiration sign is open $)^{12}$. The shape of the alpha, epsilon and theta suggests a chronology around the half of the $6^{\text {th }}$ century or soon after, in the last quarter, around $525 \mathrm{BC}^{13}$. The stone was already known in 1891 and was published in 1897 by Von Dhun who identified it as a base for a votive object ${ }^{14}$. The text was

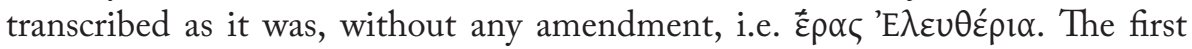
editor's interpretation was accurate: according to Van Dhun, the stone was consecrated by someone to thank Hera for his freedom. This explanation has been accepted by some scholars, but not by everyone ${ }^{15}$. Giangiulio refined the theory adding that eleuthéria could be a noun, in the neuter plural, which indicates the gift for freedom ${ }^{16}$. This hypothesis, therefore, though possible, might sound quite odd. It relies, in fact, only on one Roman inscription, found in Thessaly ${ }^{17}$. And a single comparison may not be enough. Lilian Jeffery in the 1960s studied

${ }^{11}$ Von Dhun 1897: 346-347. For an accurate reading of the stele, see Spadea Noviero 1990: 293-297, nr. 3 (with picture). Dubois 2002: 141 adds no new interpretations to the previous edition.

${ }^{12}$ For some remarks on the Achaean alphabet, see Jeffery 1961: 221-224; Guarducci 1967: 73-104; Dubois 2002: 9-11.

13 The stele has been published many times since it was found, in 1891 . For the main interpretation, after the editio princeps, which dates back to Von Dhun, see Jeffery 1961: 257 and 261, nr. 21; Pugliese Carratelli 1983: 48 (who could see three complete lines on the stone); Spadea Noviero 1990: 293-297, nr. 2 (SEG 40. 827); Arena 1996: 39; Lazzarini 1996: 245, nr. 4.4; Dubois 2002: 141 nr. 84.

\footnotetext{
${ }^{14}$ Von Dhun 1897: 346-347.

${ }^{15}$ Giannelli 1963: 142.

${ }^{16}$ Giangiulio 1983: 347-348 and Id. 1989: 19-27.

${ }^{17} I G$ 9. 2. 1034.
} 
the inscription de novo to include it in her masterpiece The Local Scripts of Archaic Greece. She edited the transcript as it follows:

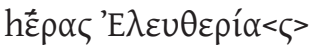

Therefore, she added a san, at the end of the second line, in pointy brackets. She went further also with the interpretation, saying that the artifact was a horos, a boundary stone, which indicated that there was a sacred area for Hera Eleutheria somewhere inside the temenos ${ }^{18}$. This exegesis has been embraced also by the latest editor of this text, Laurent Dubois ${ }^{19}$. And I agree with them too ${ }^{20}$. Briefly, this stone was to indicate, in the $6^{\text {th }}$ century, a space for Hera worshipped with the epiklesis Eleutheria ${ }^{21}$. The epithet, of course, is crucial; it reveals, in fact, a connection between the goddess and freedom (and we will see in which respect). The same association was supposed to be found also in another document, from the same archaeological context.

\subsection{Base of a marble object ... "of Hera Eleutheria"}

This is a quite puzzling item, found in 1911 in the area of the sanctuary and now kept in the National Museum of Reggio Calabria (inv.7215)22. It is a fragment of the base of a marble object, which cannot be better identified ${ }^{23}$. The inscription runs on the border. The alphabet is always Achaean, as the threebar iota and the san indicate. The paleography suggests to us a more recent date (around $450 \mathrm{BC}$ ), compared to the former inscription: one may note the dotted theta and the shape of the epsilon ${ }^{24}$. The letters still retain some traces of red color.

Though few and well written, the letters composing the text create some problems in their reading. The autopsy accomplished on the object at the time of the discovery, in fact, revealed one very significant letter that the new reading, undertaken in the 1990s, could not recognize anymore.

The first edition of the text was published by Comparetti, who read the in-

${ }^{18}$ Jeffery 1961: 261, nr. 21.

${ }^{19}$ Dubois 2002: 141-142, nr. 84.

${ }^{20} \mathrm{I}$ just would like to point out one different transcription which appeared in the huge and well known book published in 1983, namely Megale Hellas. The editor of the stone distributed the text in three lines, and this restitution is suggested in the caption of the picture (See Pugliese Carratelli 1983: 48). The missing san at the second line appeared in the third line, which, as far as I could determine, does not exist.

${ }^{21}$ See Maddoli 1983: 318-319.

${ }^{22}$ Orsi 1911: 100-101 (with drawing). The measures are: h: $0.007 \mathrm{~m}$; d. $0.045 \mathrm{~m}$. The letters are $0.005 / 0.006 \mathrm{~m}$ high.

${ }^{23}$ Orsi argued that the object could be the base of a little trapezophoros. This hypothesis, however, cannot be proved because of the fragmentary conditions of the artefact.

${ }^{24}$ Spadea Noviero 1990: 298. 
scription and suggested the apograph to Orsi. The archaeologist included it in his report of the excavations for the year 1911. In the 1990s Spadea Noviero republished a corpus of epigraphic documents from Capo Colonna; she added also pictures of the items, very helpful now, since the National Museum of Reggio has been closed for some time, and, therefore, the inscriptions have been quite difficult to reach. The transcript given by this scholar and re-used by Dubois, incidentally, is not the same as Comparetti - who has been followed by some researchers - but something new and, compared to the editio princeps, incomplete $^{25}$. To cut a long story short, the last editors (Spadea Noviero, Arena and Dubois) have rejected the last eta which Comparetti could see and which can be identified from the picture and the first available drawing. In fact, if you look at the report of Comparetti, which we could find in Orsi's remarks on the excavations, the text is $v \theta \varepsilon p i \alpha \varsigma \cdot T H$. This very last letter seems quite important, since it is the key point of the recommended integrations of the text suggested by the different scholars who have treated it. Firstly, Dubois' restoration, $\tau[\tilde{\alpha} \varsigma$ h $\hat{\varepsilon} \rho \alpha \varsigma$ $\varepsilon \mu i$

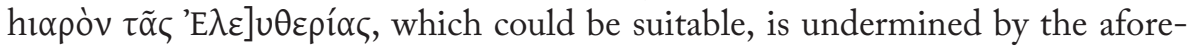
mentioned $e^{2} a^{26}$. Another restoration was argued by Comparetti, followed by Giannelli and other scholars. He proposed this transcript: T' $\delta \varepsilon \tilde{v} \alpha \alpha \dot{u} \pi \dot{\varepsilon} \rho \dot{\varepsilon} \lambda \varepsilon] \cup \theta \varepsilon \rho i ́ \alpha \varsigma^{27}$. Briefly, this was identified as a dedication made by an apeleutheros, who reached his freedom through a type of manumission usually described as sacral manumission or consecration to the goddess ${ }^{28}$. Unfortunately, this hypothesis also can hardly be accepted, for the reasons already pointed out by Spadea Noviero, but also because (as far as I know) there are no other inscriptions related to the manumission of slaves in Greece which preserve this kind of

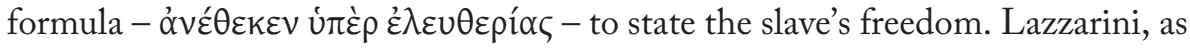
an alternative, attributes the world eleutherias to Hera. The ultimate text, there-

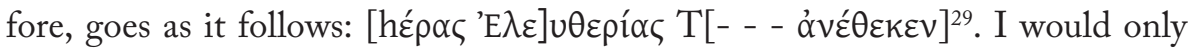
add to this that the $\mathrm{H}$, seen by Orsi and Comparetti, is evident from the picture. The fact that someone, namely TH..., dedicated this little object to Hera, grantor of freedom, is possible and makes sense. However, we should consider another possibility, which could be reinforced, in my view, by the document I am going

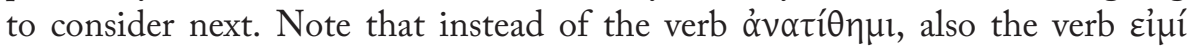

${ }^{25}$ The main editions of the text are: Orsi 1911: 101 (editio princeps); Giannelli 1963: 142; Giacomelli 1988: 40; Spadea Noviero 1990: 297-299, nr. 3; Arena 1996: 67, nr. 40; Dubois 2002: 142 , nr. 85 .

${ }^{26}$ Dubois 2002: 143.

${ }^{27}$ Orsi 1911: 101; Giannelli 1963: 142; Maddoli 1983: 319-320; Giangiulio 1989: 59, n. 24.

${ }^{28}$ On sacral manumission, see Cameron 1939: 143-179; Sokolowski 1954: 171-183; Bömer 1960: passim; Darmezin 1999: passim.

${ }^{29}$ Lazzarini 1996: 245, nr. 4.6. Spadea Noviero 1990: 298, nr. 3 adopts greater caution and gives no interpretations at all. The text is: [ - - $\dot{\lambda} \varepsilon] \cup \theta \varepsilon \rho i ́ \alpha \varsigma \tau[--]$. 
would be appropriate. In this regard, arguably a slave (TH---) or a former slave might have stated, through this little object, that he belonged to Hera ${ }^{30}$.

\subsection{Bronze foil: consecration of a slave to Hera Lacinia}

The third inscription which used to be considered in connection with the manumission of slaves is a tiny bronze foil, brought to light in 1911, completely folded up ${ }^{31}$. It was found, again, at the east of the classical temple. It is now preserved at the National Museum of Reggio Calabria, like the previous inscription $^{32}$. The presence of the iota, sigma and eta tells us that the alphabet is no longer the Achaean one; the dialect is Doric, as we can observe from the use of tas for the genitive feminine, for example ${ }^{33}$. The date can be established as $4^{\text {th }}$-century BC, without further details ${ }^{34}$. This inscription is, again, enigmatic and has been generally interpreted as a manumission text. The transcription is certain and creates no problems in the reading. On the surface it is possible

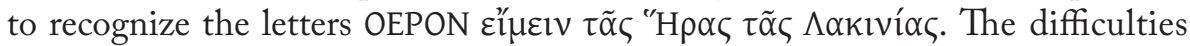
rely in the understanding of the very first part. The great majority of scholars seems to agree in considering the first letter a theta (even if the central dot is not carved) adding to the beginning of this document another foil, which arguably should have preserved the missing letters of the name apeleutheron

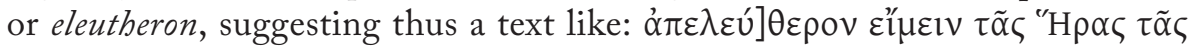
$\Lambda \alpha k i v i \alpha \varsigma^{35}$. This exegesis, theoretically speaking, can be correct and fitting the letter traces well. However, we must point out that the bronze foil is not broken on its left and right side. It is clearly original in all its borders; the assumption of another foil with just four or six letters on it in the first line, fixed close to this one while hung on the wall, for example, does not seem convincing to me. Moreover, it is rather unusual that the apeleutheros is denoted by his or her status and not by the proper name. As far as I know, almost all the manumission texts, whether consecration, sale to the divinity, or secular acts, mention the name

${ }^{30} \mathrm{I}$ am aware that, in the range of hypothesis, this could be also a speaking object, but honestly I do not know which item it could then be.

${ }^{31}$ Orsi 1911: 84, fig. 89.

${ }^{32}$ Museum of Reggio Calabria, inv. 7217. The measures: h. 0. 018; w. 0. 018. Letters: 0. 005-0. 003.

${ }^{33}$ For the main characteristics of the Doric dialect, see Buck 1955: $161 \mathrm{ff}$.

${ }^{34}$ Spadea Noviero 1990: 299-302; Dubois 2002: 147, nr. 88; Spadea 2006b: 269, nr. II. 115.

${ }^{35}$ For the very first interpretation and its rejection, see Spadea Noviero 1990: 300. This scholar published the text without restoration, but in the critical apparatus seems to agree, in some ways but not others, that the initial part is missing and, therefore, that the foil should be completed with the word apeleutheros (see also Maddoli 1983: 320). Dubois 2002: 147, nr. 88 suggests: [- - - 
of the slave or freedman ${ }^{36}$. I think, therefore, that we need to consider the text as it is, without further integrations. One more persuasive possibility (already suggested by Lazzarini) may be that the first part, theron, belongs to a proper name ${ }^{37}$. And this will be the right solution, I think. Yet, I would not augment the initial word, since, in my opinion, Theron is complete as it is. The name $\Theta \varepsilon \dot{\varepsilon} \rho \nu$ is in fact attested in the Doric realm ${ }^{38}$. In this inscription we should have the accusative case, i.e. $\Theta \varepsilon ́ p o v \alpha$, since the verb to be is conjugated as an infinitive. What I propose is therefore:

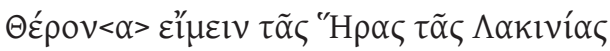

If we accept this suggestion, the inscription, as a result, cannot be straightaway included in our rather large corpus of manumission documents. We need to add some further detail. Literally, it is in fact a consecration of a person, who says to Hera, called Lacinia, that he belongs to her. I wrote a person, without specifying his status on purpose. Of course, in a speculative approach, one may think about a slave consecrated to the goddess to achieve his freedom ${ }^{39}$. This is the main clue that we are dealing with sacral manumission; a slave was transferred from the ownership of an individual to that of a god without necessarily a compulsory service to the temple ${ }^{40}$. But in the aforementioned inscription the formula is expressed with the verb to be, followed by the name of the person in accusative and of the goddess in genitive. The provision which might lead us to think about emancipation or a change of status is not perfectly traditional.

Basically, for the foil that we have, we may try to imagine also something different. The first option could be that a freedman, one apeleutheros, decided to offer his services to Hera. A similar practice, additionally, could be reminiscent of an interesting corpus of documents, found in the South of Italy and specifically

${ }^{36}$ This is considered, in fact, one of the main features of the manumission act by Calderini 1908: 199.

${ }^{37}$ Lazzarini 1996: 243-244, nr. 4. 21; Spadea 2006b: 269, II. 115 with further details.

${ }^{38}$ See $I G$ 4. 348 from Korinth; IvO 18 (Olympia). See also $I G 4.64$ and $I G$ 4. 69 from Aigina. The name is also attested in Attica, in the $6^{\text {th }}$ century $\left(I G 1^{3} 1246 ;\right.$ Agora $17.854 ; S E G$ 36 91). See also $I G 1^{3} 1227$, where the name, however, is restored.

${ }^{39}$ We may recognize a similar condition in one inscription, found one kilometer far from Capo Colonna, at Quota Cimino. It is a bronze plate now lost. Lazzarini was able to publish it thanks to a picture (Lazzarini 1998: 149-154). It dates at the beginning of the $5^{\text {th }}$ century. The text is very damaged but it is possible to decipher two key words: the verb anatithemi and the adjective hiaros in accusative. The first editor, very carefully, suggested that it could be a religious manumission of a slave. This hypothesis is embraced by Dubois, who reinforces it (Dubois 2002: 143-146, nr. 86). The plate surely is a dedication to the god Apollo, since this is perfectly readable. Regarding the interpretation of the item as a sacral manumission, I think that much caution will be required, because of the very poor condition of the text.

${ }^{40}$ See note 28. 
at Herakleia Lucana (Basilicata). These artifacts consist of nine bronze foils, that may be related to the practice of self-consecrations (with actual service, perhaps) of female slaves to the temple ${ }^{41}$. The chronology dates back to the $4^{\text {th }}$ century $\mathrm{BC}^{42}$. Most of them mention Demeter as a deity (but Kore and Hestia are also present) and were initially interpreted as dedications of women's icons to the goddesses. After a new evaluation, Maddoli suggested we consider them sacral manumissions $^{43}$. This assumption, though persuasive, surely deserves more attention. The nine foils have a peculiar formula, which is not completely distinctive of the emancipation procedure. After the mention of the ephor (which may suggest a public context for the act), there is noted the name of the devotee, which is always a woman. The verb which would state the gift of freedom for the slave is sometimes unusual, too: $\pi \alpha \rho \kappa \alpha \tau i \theta \theta \mu$ is occasionally used as a syn-

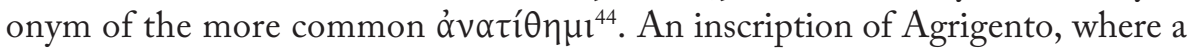
slave is perhaps consecrated to Heracles, contains a similar expression and could be a proper comparison ${ }^{45}$. The verb $\pi \alpha \rho \kappa \alpha \tau i ́ \theta \eta \mu$ is then usually followed by a

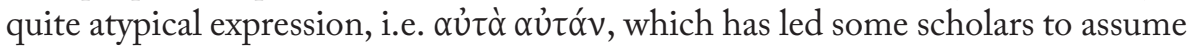
a self-consecration by the former slaves. Briefly, these women of servile origin, once having obtained their emancipation, entrusted themselves to the sanctu$\operatorname{ary}^{46}$. Though puzzling, we must admit that the link with servile manumission is the most probable solution, and it has become an even more presumptive hypothesis after a very interesting archaeological discovery of the 1980s. Two circular rings, seemingly from the sanctuary of Demeter, in fact, are intentionally opened, bound together by a rectangular bar ${ }^{47}$. The artifacts are very similar to those found in the temple of Vigna Nuova, in Crotone, positively identified with wrist and foot chains ${ }^{48}$. It would therefore be credible that even the sanctuary of Demeter could have played a role in a form of manumission that, however, is yet to be defined ${ }^{49}$.

${ }^{41}$ This is the interpretation I would propose, partially following Maddoli 1986: 99-107.

${ }^{42}$ Ghinatti 1980: 137-143, nrr. 1-9: $4^{\text {th }}$ century; Sartori 1980, 401-415, nrr. 13-21 lowers the chronology at 330-270 BC.

${ }^{43}$ See Ghinatti 1980: 137-143, nrr. 1-9 [= SEG 30. 1162-1170]. For new acquisitions and a revised exegesis, see Sartori 1980: 401-415, nrr. 13-21; Maddoli 1986: 99-107.

${ }^{44} \mathrm{On}$ the formulas that can be found in sacral manumission texts, see now VelissaropoulosKarakostas 2011: 378-398.

45 SEG 42. 823.

${ }^{46}$ Maddoli 1986: 99-107.

${ }^{47}$ Pianu 1989: 98.

${ }^{48}$ The main comparison is provided by the chains of the silver mines of the Laurion (see Lauffer 1979: 52-56). Similar chains were also brought to light in the sanctuary of Timmari, which can be identified as a temple of Demeter and at San Chirico Nuovo (Basilicata), where Artemis seems to be the main goddess. For the status quaestionis, see Gertl 2014: 236.

${ }^{49}$ See also Prandi 2008: 126-129. It is useful to remember that Demeter was worshipped in 
Accordingly, I shall try to suggest a second conjecture concerning the bronze foil found at Capo Colonna, with the name of Theron. One may note that slaves could in fact go to temples not only to ask for freedom, but also to seek refuge. They did not thereby become freedmen; they continued to be slaves but they might become chattels of another master. In this respect, it is useful to remember that runaway slaves are attested by the sources in a number of sanctuaries which were able to grant them asylia. The slaves used to go to the Theseion, at Athens, for instance, to save themselves from the harsh treatment of their master. Once there, they did not change their status, becoming apeleutheroi; they simply wanted to be resold, i.e. to change their despotes ${ }^{50}$. We can infer something very similar from the inscription on the mysteries of Andania ${ }^{51}$. The slaves who arrived at the temple from Messene were judged by the priest, who could send them back to their master or not; in this very last case, they probably stayed in the sanctuary and served as sacred slaves ${ }^{52}$.

Briefly, they became bierodouloi $i^{53}$.

The consecration of slaves in the temple of Hera at Capo Colonna perfectly suits what Plutarch, in the Life of Pompey, tells us about the nature of the sanctuary; he says, in fact, that this Heraion was an asylon, that is to say that it was inviolable and that it assured personal freedom and safety to the ones who seek refuge there ${ }^{54}$. This important feature was shared by to two other sanctuaries, quoted by Plutarch, namely the Heraion in Argos and the one in Samos. Both these sacred areas, in fact, attest inscriptions related to the manumission of slaves: in Argos some catalogues with servile names were interpreted as lists of manumitted slaves ${ }^{55}$. The chronology, yet, is quite late (late Hellenistic and Imperial Period). In Samos, a document dated to 245/4 BC attests the presence of fugitive slaves coming to the temenos to seek refuge. The central part of the inscription (which comprises three different fragments) is a letter written by

Tarentum and Syracuse with the epithet epilysamène, i.e. eleutheria. Hsch. s. v. 'E $\pi \imath \lambda \cup \sigma \alpha \mu \varepsilon ́ v \eta$. See Nafissi 1995: 179-180. The connection with freedom, therefore, becomes closer.

${ }^{50}$ Poll. 7. 13. See also Plu. Mor. 166d. V. Christensen (1984) [1990]: 23-25; Kudlien 1988: 232-252; Chaniotis 1996: 65-86; Gottesmann 2014: 160-163.

${ }^{51}$ ISCG 65, 11. 80-84, commented in Gawlinski 2012, 187-194.

${ }^{52}$ Chaniotis 1996: 81. Observe an example in one novel of Achilles Tatius (7.13) where the procedure followed in the Artemision of Ephesus is explained. We know that if the master of the suppliant was not guilty, he could bring his slave back. If, instead, he had committed a sort of injustice, the slave could stay in the temple as hieros doulos of the goddess. Something similar is also attested in Selected Papyri 3, fr. 48, from an anonymous author, maybe Alexis: here a

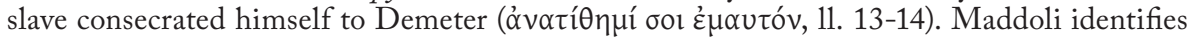
the character in Alexis with a freedman. I am not so convinced of this interpretation. I agree with Sartori (Sartori 1988: 277), moreover, that this man could be a slave.

${ }^{53}$ See Debord 1972: 135-150; Bömer 1960: 123. See also NP s.v. bierodouloi.

${ }^{54}$ Plu. Pomp. 24.

${ }^{55} I G$ 4. 529 and 530; SEG 42. 279. 
Ptolemy III, concerning several regulations about these slaves, who are precisely mentioned at lines 9 and $10^{56}$. One more piece of information comes from a passage of Stephanus of Byzantium ${ }^{57}$. At the entry Sybaris he tells us of an oiketes, a slave, who was being whipped by his owner. So he went and sought refuge at the altar of Hera en agro; the goddess was in fact the protector of suppliants. I must say, moreover, that one Heraion placed out of the town $\left(\dot{\varepsilon} \vee \pi \varepsilon \delta \delta^{\prime} \mathrm{l} \imath\right)$ is quoted by an inscription carved on a ritual bronze axe ${ }^{58}$. In this regard, the document of Theron who becomes of Hera Lacinia, shows two complementary features of the goddess, protector of both manumitted and runaway slaves.

\subsection{Fragments of bronze foils}

If we go further with the data we have about slaves, freedom and manumission in the temple of Hera in Kroton, we need to consider also some other bronze foils, found in the sanctuary and for the most part published by Lazzarini in the $1980 \mathrm{~s}^{59}$. On one fragment (though very badly damaged) we can recognize, again, the connection between Hera and the word eleutheria ${ }^{60}$.

\section{The ChaIns}

I think that the chains that were found in another temple of Kroton, called Vigna Nuova, ought at this time to be gaining more attention. The temple is situated next to the walls, in a place where now there is an industrial area which was convincingly identified as a Heraion ${ }^{61}$. The bronze artifacts are interesting and used to be considered a kind of unicum: they all are wrist and foot chains, but the striking thing is that they have been broken with a mallet. As it has been suggested, they probably attest to a gift of freedom for many slaves, working somewhere on the territory of Kroton as prisoners. When manumitted, in fact, captives sometimes used to dedicate the symbols of their previous subjugation

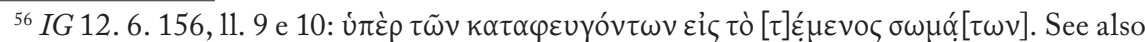
Habicht 1957: 226-231.

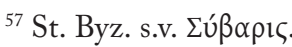

${ }^{58} I G$ 14. 643. See also Dubois 2002: 32, nr. 9, with previous bibliography. The bronze axe was found at San Sosti, Sybaris, in 1846. It is now preserved at the British Museum, inv. 252. For a commentary, see also Lucca 1994: 49-52.

59 The first mention of these items can be found in a note suggested by Lazzarini during the congress held at Taranto in 1983 (Lazzarini 1983: 353-355). She presented there six foils; two more were published by Gasperini 1986: 154-157. They are presented all together in Lazzarini 1996: 242-246, 4. 11- 4. 20.

${ }^{60}$ Lazzarini 1996, 245, 4. 14. The texts is: $[--] \mathrm{l}[----] /[--] \varepsilon \varsigma \mathrm{h}[---] /[--]$ $\varepsilon \lambda \varepsilon \cup[---] /[--]$ hē $\rho \alpha[--]$.

${ }^{61}$ Spadea 1997: 235-259. Cf. also Leone 1998: 16-18 concerning the walls. For the identification as a temple for Hera, see Spadea 1983: 144-150. 
to a deity. According to this supposition, it becomes much more interesting that in an area called Acqua di Friso, near Cropani, some chains very similar to the ones of Vigna Nuova were discovered during the excavations ${ }^{62}$. The sanctuary which contained them, once again, can be identified with a Heraion. And, as I have already mentioned, similar chains were also present in two sanctuaries, one for Demeter and one for Artemis, in Basilicata ${ }^{63}$. This sort of ritual consecration of the symbols of the slavery by those freed, is attested in the Greek motherland and particularly in Phlius, on the acropolis. Pausanias, in fact, tells us that the prisoners, once set free, dedicate their chains, hanging them up to the trees in the wood $^{64}$.

For Kroton, the literary sources tell us that the tyrant Kleinias decided to give freedom to a large group of slaves, employed as farmers in the plain of Sybaris, in the $5^{\text {th }}$ century, and this event, one may say, could be the reason to break the chains and consecrate them to Hera, hypothetically Hera Eleutheria ${ }^{65}$. However, it is worth remembering that - though fascinating - the hypothesis is scarcely supported by corroborating sources. Moreover, the literary topos of the anti-aristocratic tyrant, who uses the slaves for his purpose, granting them freedom, might also be well-fitting for the tyrant Kleinias ${ }^{66}$.

\section{HERA: PROTECTOR OF SLAVES AND GRANTOR OF FREEDOM}

To sum up, Hera was called Eleutheria in the inscriptions: she was worshipped as the protector of slaves (manumitted or sacred slaves) and grantor of freedom. One may wonder, therefore, if these features of the goddess were attested also in the Greek motherland. And the answer seems to be positive.

${ }^{62}$ The materials are unpublished, as far as I know. The news of the discovering of the chains is given in the catalogue of the Antiquarium, edited by M. G. Aisa, superintendent of the excavations of the area.

${ }^{63}$ See supra, n. 48.

${ }^{64}$ Paus. 2. 13. 4. We know also two more parallels of chains exposed as symbols of enslavement, but they refer to specific episodes and therefore are not really indicative of a practice. In Athens, Herodotus indicates the presence, on the Acropolis, of the chains with which the Athenians enslaved the Boeotians and the Chalcidians in $506 \mathrm{BC}$ (Hdt. 5. 77. 4). The bronze chariot, obtained thanks to the ransom paid by the prisoners for their release, is noted also by Paus. 1. 28. 2. See also $I G 1^{3} 501$. For a commentary of the sources linked with the chariot and its position on the Acropolis, see Monaco 2010: 275-311 and Berti 2012: 9-95 and especially 9-25. Similarly, in the temple of Athena Alea at Tegea, were clearly visible, despite the rust, the chains with which the Spartans had been enslaved by the Tegeans. The story, which can be placed in the first half of the sixth century, is told, once again, by Herodotus (Hdt. 1. 66; Paus. 8. 47. 2). On the chronology, see Moretti 1962: 22-23; Vannicelli 1993: 57-67.

${ }^{65}$ D. H. 20. 7. Spadea 1983: 327.

${ }^{66}$ About the tyrant Kleinias, see Luraghi 1994: 71-76, who underlines how Kleinias follows the stereotype of the bad tyrant. See also Asheri 1977: 21-48 and Nafissi 2004: 170 n. 66 . 
One Hellenistic document, found in Crete and dated to the $2^{\text {nd }}$ century $\mathrm{BC}$, provides a useful clue ${ }^{67}$. It is a decree from the polis of Gortyn. The demos was to decide some regulations connected to freedmen and the obligations they have to consecrate a silver phiale to the oikos of Hera to reach complete freedom. The text is singular and full of interest. The phiale, in fact, leads us to some important considerations about the cult of Hera and its possible connection with the manumission of the slaves.

The phiale is a quite common dedicatory object, and often intended for Hera ${ }^{68}$. It is linked with libations, sacrifices and above all with water, which was a very important element in the rituals celebrated for the goddess ${ }^{69}$. We know that at the Heraion of Argos special services which involved a bath for Hera's cult image and other ceremonies of purification were performed. Little hydriai and phialai (especially mesomphalic ones) were found in the archaeological excavations at the Heraia of Argos and of Perachora ${ }^{70}$. Water was a symbol of purification and was peculiar to this rite of passage. And the change of status that affected the slave through emancipation surely involved a sort of ceremony ${ }^{71}$. It is no surprise, therefore, that the phiale was specifically chosen by the manumitted slaves as an offering to thank the divinity for freedom. Also in Athens, in fact, as we know from the Attic inscriptions, commonly called also phialai exeleutherikai, a silver bowl (of the value of one hundred drachmas) was the dedication offered by the emancipated slaves, who had completely acquitted their obligations to their previous masters ${ }^{72}$.

${ }^{67}$ Magnelli 1998: 95-113 and Id. 2008: 294-296.

${ }^{68}$ See Luschey 1939: 7-9 and 41-60.

${ }^{69}$ Cole 1988: 161-165. See also Barra Bagnasco 1999: 34. Cf. Tomlinson 1988: 167-171 with a quite different point of view on the role of water in rituals.

${ }^{70}$ Many phialai were found in the Heraion of Samos (see Ohly 1953: 25 ss.); at Perachora (Dunbabin 1951: 61-71; for a different interpretation see Tomlinson 1988: 167-171) and at Argos (Caskey - Amandry 1952: 179-180). At the Heraion of Capo Colonna some phialai were attested too.

${ }^{71}$ Manumission as a ritual is attested by a number of sources (Hatzopoulos 1994: 113-122; see also Kamen 2005: 137-187). Many of them will be listed in the text. I would also add the passage of Thucydides who says that the Spartan Helot, who was to set free, was crowned with flowers and brought to the main sanctuaries to be introduced as free men (Th. 4. 80 . 2-3). It is noteworthy also that in Athens, for instance, the manumission of the slaves could be announced by the herald during the Great Dionysia, when other rituals linked to the change of social status were accomplished. On the specific use of water as part of the manumission see also Gertl 2014, dealing with the sanctuary of Demeter at Herakleia Lucana.

72 On the phialai inscriptions, see Lewis 1959: 208-238 (= SEG XVIII 36); Id. 1968: 368380 (= SEG XXV 180). See also Meritt 1961: 247 (= SEG XXI 561); Walbank 1994: 179-180 (= SEG XLIV 68); Id. 1996: 452-458 (= SEG XLVI 180-184). A new fragment belonging to the corpus is now published by Malouchou 2012: 201-215. The corpus consist of a number of texts which are traditionally considered the written record of a private lawsuit, a dike, moved by the master to his apeleutheros who went to live apart or did not accomplish the 
Some inscriptions, found in Macedonia (most of them come from Beroia), attest the dedication of phialai, but also other kinds of vessels, such as skyphoi, by a group of apeleutheroi ${ }^{73}$. The following document provides us an insight into the context ${ }^{74}$ :

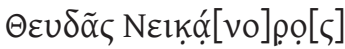

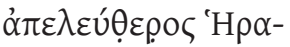 \\ $\kappa \lambda \varepsilon \tilde{\imath} \varphi \imath \alpha \lambda i ́[\sigma] \kappa \sigma^{\prime}$}

The deity to whom offerings were directed is Heracles, who is often identified by the epiklesis Kynagidas. Protector of the transitions of young boys, who were preparing to enter adulthood physically and legally, Heracles certainly has the potential to become the tutelary deity also of the passage (in this case legal and social) leading to the change of status of the slave, who through the ceremony of emancipation managed to participate in a form of freedom, albeit partial ${ }^{75}$. Manumission, therefore, assumes the characteristics of a rite of maturation, which allows a social renewal.

The connection between the act of drinking and the gift of freedom may exist also in a Cretan inscription, dated around $500 \mathrm{BC}^{76}$. The text is boustrophedon and the alphabet is Cretan. The text is very fragmentary, but still keeps the key formula of manumission acts. At line 3 we can recognize part of the word eleutheros, namely free (with digamma at the beginning of the line). At line 4 dolos, that is to say doulos, is readable. At line 6 we can see the verb lagaien that, in Cretan dialect, seems to be used as a synonym of "set free" (and here we can see the peculiar gamma and the three-bar iota $)^{77}$. Finally, the last line still preserves the word pinen, from the verb pino, to drink (with the peculiar shape of $p i$ and iota). Van Effenterre and Ruzé, who published the document in their collection

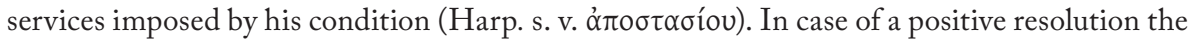
freedman used to consecrate a silver phiale of the value of one hundred drachmas. This silver bowls are reminded as phialai exeleutherikai in two inscriptions (IG $2^{2} 1469$ and 1480). For an interpretation of the corpus see Rocca 2011: 248-268. Zelnick-Abramovitz 2013: 96 ss. and Kamen 2013: 32-54. For a new interpretation of the inscriptions see Meyer 2010; for some criticism see $B E 2011$, nr. 244.

${ }^{73}$ EAM 30; EKM 31-33.

${ }^{74}$ EAM 30 .

${ }^{75}$ Hatzopoulos 1994: 110.

${ }^{76}$ IC 4. 62. See also Jeffery 1961: 413, fig. 59, nr. 3; Effenterre-Ruzé 1995: 34, nr. 3. The inscription was found near the residential area of Mitropolis, at Gortyn, and is now kept at the Museum of Heraklion. Scholars proposed to recognize the document, which is related to the manumission of slaves, as a fragmentary law to regulate the ways to set a slave free.

77 The verb is attested in inscriptions $I C$ 4. 233-236; it also appears in the inscription $I C$ 4. 25. 4, found in Anoia and dated to the first century AD. On the status of the manumitted slaves in Crete, see Willets 1955: 37-45. 
of juridical texts, Nomima, wrote that this expression could be understood in connection with some kind of celebration ${ }^{78}$. And, in my opinion, it should be.

The use of drinking and using water after or during the manumission with bowls and kraters is attested in the literary sources. Already in the Iliad we read about the krater called eleutheron ${ }^{79}$. In the comedy we can find some examples about prostitutes and women drinking the water of freedom (and in one case, ironically, the wine of freedom) to reach their manumission ${ }^{80}$. The adjective used to characterize this beneficial water is eleutherion. And, in fact, Hesychius, in his Lexicon wrote that a spring called eleutheron hudor, placed near Argos, was drunk by the manumitted slaves to reach and celebrate their freedom ${ }^{81}$. This statement is supported by two other sources, namely Eustathius and, especially, Pausanias who confirms that near the Heraion a river called "of freedom" ( $\delta \omega \rho$

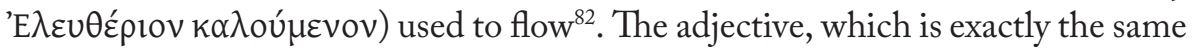
as that of Hera Eleutheria, as a result, characterizes without doubt a special ritual to set slaves free, and it is also connected with the drinking bowls, as we have seen before. No surprise, therefore, that in the sanctuary excavated at Acqua di Friso (Cropani) and probably identified as an Heraion hydriai and similar vessels were found in the excavations too.

As a final point, one may go further, adding to these sources one inscription found in Noto, in Sicily (near Syracuse), now in the museum of Palermo ${ }^{83}$. The surface of the stone is quite damaged but still readable. We must say in advance that the document can be placed around the $1^{\text {st }}$ century $\mathrm{BC}$ or soon after. Nonetheless, the text is very interesting and - in my opinion - well fitting for our argument. A man, Eubulidas, son of Agatharchos, from Centuripe, build

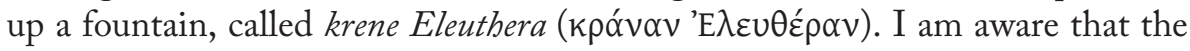
meaning of the text can be interpreted in other ways, but it sounds quite peculiar to me that a fountain, built by a private person, once more, brings up the name of Freedom. In fact, the connection with purity and with the cleansing power of the water, again strongly comes to my mind.

${ }^{78}$ Van Effenterre - Ruzé 1994: 34.

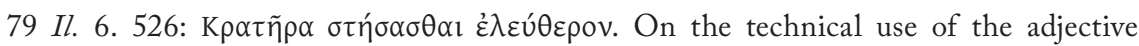
eleutheros in Homer (it appears only twice), see the commentary of Kirk 1990: 219 and 228229.

${ }^{80}$ Antiph., PCG fr. 26 (apud Ath. 3. $123 \mathrm{~b}$-c) where it is said that one hetaira drinks the water of freedom; Aristophon, $P C G$ fr. 13 (apud Ath. 11. $472 \mathrm{c}-\mathrm{d}$ ) where one girl is immersed in the water of freedom; Xenarch., PCG fr. 5 (apud Ath. 10.440 e) where the water of freedom comically becomes the wine of freedom. See also Theop. Com., PCG fr. 66.

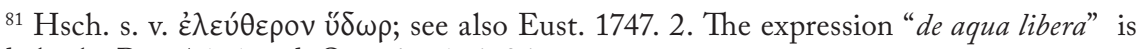
used also by Petr. 71, 1 and Ov., Am.1.6.26.

${ }^{82}$ Paus. 2. 17. 1.

${ }^{83}$ Manni Piraino 1973: 54, nr. $29=I G$ 14. 241. 


\section{Conclusions}

In conclusion: we have two inscriptions (texts 1 and 2) found in the Heraion of Capo Colonna, near Kroton, which reveal a noteworthy feature of Hera, worshipped there as Eleutheria. Although no proper manumission text is available so far, the freedom-seeking is implicit in the name of the goddess. In addition, one might recognize in two texts ( 2 and 3 ) the consecration of two slaves to Hera, and this reminds us also of the role of asylum that the sanctuary used to have. Two more Heraia in the motherland are places where the slaves, as suppliants, could seek refuge, and this characteristic seems to be proper to an altar in Sybaris (but we have no archaeological evidence for that). We have seen also that in two Heraia near Kroton (one in Vigna Nuova and probably one in Cropani) some wrist and foot chains broken with a mallet were found and that these items may refer to some prisoners, who were set free all together. Finally, the adjective eleutherios/eleutheros appears to be strongly related with water and rituals connected to it (drinking, immersing) for release from slavery. In Gortyn the sanctuary of Hera was the place where a manumitted slave could achieve the complete freedom, by dedicating a silver phiale. And I have argued that this object, again, may recall water and its liberating power.

As a result, it seems quite clear now that the inscriptions found at the Heraion of Capo Colonna deserve a closer attention, since they are strongly connected with the ritual itself of manumission that, in the Greek motherland, is scarcely documented but not unattested. Water, drunk and aspersed, took a primary role. Hera Eleutheria was the protector of the runaway slaves and of the freedman that did go to her sanctuaries to thank her for their freedom or to look for protection from the archaic period onward. I would also go further with the interpretation, saying that a specific place was probably dedicated to Hera Eleutheria within the sanctuary of Capo Colonna, and I believe that the area itself was a special one, because of the ritual, the water and the quite mystic place. The same assumption might work also for Vigna Nuova and, quite possibly, for Acqua di Friso.

The words of the Emperor Hadrian written by M. Yourcenar come to my mind: "Water drunk more reverently still, from the hands or from the spring itself, diffuses within us the most secret salt of earth and the rain of heaven". And the slaves became free.

\section{Bibliography}

Albrecht, K. D. (1978), Rechtsprobleme in den Freilassungen der Botier, Phoker, Dorier, Ost und Westlokrer. Paderborn.

Asheri, D. (1977), "Tyrannie et mariage forcé. Essai d'histoire sociale grecque", $A E S C_{32: 2 \text { I-48. }}$ 
Arena, R. (1996), Iscrizioni greche arcaiche di Sicilia e Magna Grecia IV. Iscrizioni delle colonie achee. Alessandria.

Aversa, G. (2006), "Lo sviluppo del santuario di Hera Lacinia: problematiche generali e nuove ipotesi”, in R. Spadea (ed.), Ricerche nel santuario di Hera Lacinia a Capo Colonna di Crotone. Roma, 31-49.

Barra Bagnasco, M. (1999), "Il culto delle acque in Basilicata dall'età arcaica alla romanizzazione: documenti archeologici e fonti letterarie", in M. L. Nava (ed.), Archeologia dell'acqua in Basilicata, Soprintendenza Archeologica della Basilicata. Lavello, 25-52.

Belli Pasqua, R. (2006), "I culti del Lacinio", in R. Spadea (ed.), Il Museo del Parco Archeologico di Capo Colonna a Crotone. Crotone, 37-39.

Belli Pasqua, R., Spadea, R. (2005) (eds.), Kroton e il suo territorio tra VI e V secolo a.C. Aggiornamenti e nuove ricerche. Atti del convegno, Crotone 3-5 marzo 2000. Crotone.

Berti, S. (2012), "La dedica degli Ateniesi per la vittoria su Beoti e Calcidesi del 506 a.C. (IG I3 501) e la sua collocazione", Istituto Lombardo (Memorie di Lettere) 43: 9-96.

Bömer, F. (1960), Untersuchungen über die Religion der Sklaven in Griechenland und Rom, vol. II: Die sogennnate sakrale Freilassung in Griechenland und die

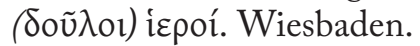

Buck, C. D. (1955), The Greek Dialects. Chicago.

Calderini, A. (1908), La manomissione e la condizione dei liberti in Grecia. Milano.

Cameron, A. (1939), "Inscriptions Relating to Sacral Manumission and Confession”, HThR 32: 143-179.

Caskey, J. L., Amandry, P. (1952), "Investigations at the Heraion of Argos, 1949”, Hesperia 21: 165-221.

Chaniotis, A. (1996), "Conflicting Authorities: Asylia between Secular and Divine Law in the Classical and Hellenistic Poleis", Kernos 9: 65-86.

Christensen, K. A. (1984), "The Theseion: a Slave Refuge at Athens", American Journal of Ancient History 9: 23-32.

Cordiano, G. (2000), "La fine della "ierodulia" femminile a Temesa Magno Greca nella propaganda dei Locresi Epizefirii”, ARYS 3: 115- 127.

Crotone (1983), Crotone. Atti del del XXIII Convegno Internazionale di Studi sulla Magna Grecia (Taranto-Crotone, 1983). Taranto.

Crotone (1993), Crotone e la sua storia tra IV e III secolo a.C. Atti del Seminario Internazionale (Napoli, Univ. Federico II. Dipartimento di Discipline Storiche, 1987). Napoli. 
Darmezin, L. (1999), Les affranchissements par consécration en Béotie et dans le monde grec hellénistique. Paris.

Débord, P. (1972), «L'esclavage sacre. Etat de la question», in Actes du colloque 1971 sur l'esclavage. Besançon, 135-150.

Drachman, A. B. (1878), De manumissione servorum apud Graecos, quale ex inscriptionibus cognoscimus. Copenhagen.

Dubois, L. (2002): Inscriptions grecques dialectales de Grande Grèce. Tome II. Colonies Achéennes. Genève.

Dunbabin, T. J. (1951), "The oracle of Hera Akraia at Perachora", ABSA 46: 61-71.

Gasperini, L. (1986), "Vecchie e nuove epigrafi dal Bruzio Ionico", in Decima miscellanea greca e romana. Roma, 154-157.

Gawlinski, L. (2012), The Sacred Law of Andania: a New Text with Commentary, Berlin-Boston.

Gertl, V. (2014), "Acque risorgive, pozzi sacri e pratica rituale nel santuario di Demetra a Policoro, MT (Herakleia in Lucania)”, Mem. Descr. Carta Geol. d'It. 96: 227-238.

Ghinatti, F. (1980), "Nuovi efori in epigrafi di Heraclea Lucana", in Forschungen und Funde. Festschrift B. Neutsch. Innsbruck, 137-143.

Giacomelli, R. (1988), Achaea Magno-Graeca. Le iscrizioni arcaiche in alfabeto acheo di Magna Grecia. Brescia.

Giangiulio, M. (1989), Ricerche su Crotone arcaica. Pisa.

Giannelli, G. (1963), Culti e miti della Magna Grecia: contributo alla storia più antica delle colonie Greche in occidente. Firenze.

Gottesman, A. (2014), Politics and the Street in Democratic Athens. Cambridge.

Guarducci, M. (1967), Epigrafia Greca I. Caratteri e storia della disciplina. La scrittura greca dalle origini all'età imperiale. Roma.

Guettel Cole, S. (1988), "The uses of water in Greek sanctuaries”, in R. Hägg N. Marinatos - G. C. Nordquist (eds.), Early Greek Cult Practice. Proceedings of the Fifth International Symposium at the Swedish Institute at Athens, 26-29 June, 1986. Stockholm, 161-165.

Guzzo, P. G. (2014), “Doni ad Hera Lacinia”, in R. Spadea (a cura di), Kroton. Studi e ricerche sulla polis achea e il suo territorio. Roma, 509-517.

Hatzopoulos, M. (1994), Cultes et rites de passage en Macédoine. Athènes.

Jeffery, L. H. (1961), The Local Scripts of Archaic Greece : a Study of the Origin of the Greek Alphabet and its Development from the Eighth to the Fifth Centuries b. C. Oxford. 
Kamen, E. D. (2005), Conceptualizing Manumission in Ancient Greek (PhD Dissertation, University of California. Unpublished). Berkley .

Kamen, E. D. (2013), Status in Classical Athens. Princeton.

Kirk, G. S. (1990), The Iliad: a commentary. Volume II: books 5-8. Cambridge.

Klees, H. (1998), Sklavenleben in Klassischen Griechenland. Forschungen zur antiken Sklaverei 30. Stuttgart.

Klees, H. (2000), "Die rechtliche und gesellschaftliche Stellung der Freigelassenen im klassichen Griechenland", Laverna 11: 1-43.

Kranzlein, A. (1983), "Bemerkungen zu den griechischen Freilassungsinschriften”, Symposion 1979. Köln, 239-247.

Kudlien, F. (1988), «Zur sozialen Situation des flüchtigen Sklaven in der Antike», Hermes 116: 232-252.

La Genière, I (ed.) (1997), Hera. Images, Espaces, Cultes. Actes du Colloque International du centre de Recherches Archéologiques de l'Université de Lille et de l'Association P. R. A. C. (Lille, 29-30 novembre 1993). Lille.

Lauffer, S. (1979), S. Lauffer, Die Bergwerkssklaven von Laureion. Wiesbaden.

Lazzarini, M. L. (1983), «Intervento», in Crotone 1983, 353-355.

Ead. (1996), «Le iscrizioni del Lacinio», in G. Pugliese Carratelli (ed.), I Greci in Occidente. Milano, 242-246.

Ead. (1998), "Una nuova testimonianza del culto di Apollo a Crotone”, in G. Greco- S. Adamo Muscettola (eds.), I culti della Campania antica, Atti del convegno di studi in ricordo di Nazarena Valenza Mele. Napoli, 149-154.

Leone, R. (1998), Luoghi di culto extra-urbani d'età arcaica in Magna Grecia. Firenze.

Lewis, D. (1959), “Attic Manumissions”, Hesperia 28: 208-238.

Lewis, D. (1968), "Dedications of Phialai at Athens", Hesperia 37: 368-380.

Lombardo, M. (2011), "Le fondazioni achee in Italia meridionale. Fonti e problemi storici", in L. Droulia, A. D. Rizakis (eds.), L'Acaia e l'Italia meridionale. Contatti, Scambi e relazioni dall'antichità ai nostri giorni. Atti del Convegno, Eghio, 6-9 Luglio 2006. Atene, 22-46.

Lucca, R. (1994), "HEPA EN ПE $I \Omega I$ I. Per la cultualità di Sibari”, in L. Braccesi (ed.), Hesperia 4. Studi sulla grecità di Occidente. Venezia, 49-52.

Luraghi, N. (1994), Tirannidi arcaiche in Sicilia e Magna Grecia : da Panezio di Leontini alla caduta dei Dinomenidi. Firenze.

Lushey, H. (1939), Die Phiale. Bleicherode am Harz.

Maddoli, G. (1984), "I culti di Crotone", in Crotone 1983, 311-343.

Id. (1986): "Manomissioni sacre in Eraclea Lucana”, PP 41: 99-107. 
Magnelli, A. (1998), "Una nuova epigrafe gortinia in materia di manomissione”, Dike 1: 95-113.

Magnelli, A. (2008), "Decreto dell'assemblea gortinia sulla manomissione servile, metà del sec. II a. C.”, RAL 155: 294-296.

Malochou, G. (2012), "The overlooked Attic Inscriptions", in P. Martzavou N. Papazarkadas (eds.), Epigraphical Approaches to the Post-classical Polis: Fourth Century BC to Second Century AD. Oxford, 201-215.

Manganaro, G. (2004), “Anagrafe di Leontini nel V secolo (a proposito di una tavoletta bronzea dedicatoria di V sec. a.C.)”, ZPE 149: 55-68.

Manni Piraino, M. T. (1973), Iscrizioni greche lapidarie del Museo di Palermo. Palermo.

Mele, A. (1983), "Crotone e la sua storia", in Crotone 1983, 9-87.

Id. (1996), I culti di Crotone, in G. Pugliese Carratelli (ed.), I Greci in Occidente. Milano, 235-238.

Meritt, B. (1961), “Greek Inscriptions”, Hesperia 30, 205-292.

Meyer, E. (2010), Metics and the Athenian Phialai - Inscriptions. A study in Athenian Epigraphy and Law. Stuttgart.

Meyer, E. (2013), The Inscriptions of Dodona and a New History of Molossia. Heidelberg

Monaco, M. (2010), "Sull'acropoli, all'ombra della Promachos", ASAtene 87: 275-311.

Moretti, L. (1962), Ricerche sulle leghe greche: Peloponnesiaca-Beotica-Licia. Roma.

Nafissi, M. (1995), Le fonti letterarie ed epigrafiche, in E. Lippolis - S. Garraffo - M. Nafissi (eds.), Culti greci in Occidente, I. Taranto. Taranto, 153-334.

Nafissi, M. (2004), “Tucidide, Erodoto e la tradizione su Pausania nel V secolo”, RSA 34: 147-180.

Ohly, D. (1953), "Die Gottin und ihre Basis”, $A M$ 68: 25-50.

Orsi, P. (1911), "Prima campagna di scavi al Santuario di Hera Lacinia", in Notizie degli Scavi, Suppl. 1911, 77-118.

Pianu, G. (1989), Scavi al santuario di Demetra a Policoro, in M. Torelli (ed.), Studi su Siris-Heraclea. Roma, 95-112.

Prandi, L. (2008), "La documentazione letteraria ed epigrafica”, in: M. Osanna - L. Prandi - A. Siciliano (eds.), Culti greci in Occidente II, Eraclea Lucana. Taranto, 117-143.

Pugliese Carratelli, G. (1983), Megale Hellas. Storia e civiltà della Magna Grecia. Milano.

Rädle, H. (1969), Untesuchungen zum griechishen Freilassungwesen. Munchen. 
Rocca, F. (2011), "IG II2 1560 e la pratica della manomissione ad Atene: alcune osservazioni", Historikà 1: 247-268.

Sartori, F. (1980), "Dediche a Demetra in Eraclea Lucana", in Forschungen und Funde, Festschrift B. Neutsch. Innsbruck, 401-415.

Sartori, F. (1992), "Ancora sulle dediche a Demetra in Eraclea Lucana”, in M. M. Mactoux - E. Geny (eds.), Mélanges Pierre Levếque. 6, Religion. Besançon, 269-277.

Sokolowski, F. (1 954), “The Real Meaning of Sacral Manumission”, HThR 47: 173-181.

Spadea, R. (1983), "La topografia”, in Crotone 1983, 119 - 166.

Spadea, R. (1996), "Il santuario di Hera", in R. Spadea (ed.), Il tesoro di Hera, scoperte nel santuario di Hera Lacinia a Capo Colonna di Crotone. Milano, 33-50.

Spadea, R. (1997), "Santuari di Hera a Crotone”, in I. de La Genière (ed.), Hera. Images, Espaces, Cultes. Actes du Colloque International du centre de Recherches Archéologiques de l'Université de Lille et de l'Association P. R. A. C. (Lille, 29 - 30 novembre 1993). Lille, 235-259.

Spadea, R. (2006a), "Il santuario di Hera Lacinia: storia recente", in R. Spadea (ed.), Ricerche nel santuario di Hera Lacinia a Capo Colonna di Crotone. Roma, 13-29.

Spadea, R. (2006b), "Paolo Orsi a Capo Colonna", in S. Settis - M. L. Parra (eds.), Magna Graecia. Archeologia di un sapere. Catalogo della mostra (Catanzaro, Complesso Monumentale, 19 giugno-31 ottobre 2005). Milano, 264272.

Spadea, R. (2006c), "L'Edificio B”, in R. Spadea (ed. ), Il Museo del Parco Archeologico di Capo Colonna a Crotone. Crotone, 43-46.

Spadea, R. (2009), "Capo Colonna: cronache di scavi, di ricerche e di tutela”, in C. Mezzetti (ed.), Il santuario di Hera al Capo Lacinio: l'analisi della forma, il restauro e la ricerca archeologica. Roma, 63-90.

Spadea, R. 2014 (ed.), Kroton. Studi e ricerche sulla polis achea e il suo territorio. Roma.

Spadea Noviero, G. (1990), "Documenti epigrafici del santuario di Era Lacinia a Capo Colonna”, PP 253: 289-312.

Tomlinson, R. A. (1988), "Water supplies and ritual at the Heraion Perachora", in R. Hägg - N. Marinatos - G. C. Nordquist (eds.), Early Greek Cult Practice. Proceedings of the Fifth International Symposium at the Swedish Institute at Athens, 26-29 June, 1986. Stockholm, 167-171. 
Van Effenterre, H., Ruzé, F. (1994), Nomima. Recueil d’inscriptions politiques et juridiques de l'archaisme grec, I-II. Rome.

Vannicelli, P. (1993), Erodoto e la storia dell'alto e medio arcaismo: Sparta-Tessaglia-Cirene. Roma.

Velissaropoulos-Karakostas, I. (2011), Droit grec d'Alexandre a Auguste (323 av.J.C.-14 ap. J.C.): Personnes, Biens, Justice. Tome I E II. Athènes.

Von Dhun, F. (1897), "Antichità greche di Crotone”, in Notizie degli scavi, 343360.

Walbank, M. B. (1994), "Greek Inscriptions from the Athenian Agora: Lists of Names”, Hesperia 63: 169-209.

Walbank, M. B. (1996), "Greek Inscriptions from the Athenian Agora: Financial Documents”, Hesperia 65: 433-465.

Willetts, R. F. (1955), Aristocratic Society in Ancient Crete. London.

Zelnick-Abramovitz, R. (2005), Not Wholly Free. The Concept of Manumission and the Status of Manumitted Slaves in the Ancient Greek World. Leiden-Boston.

Zelnick-Abramovitz, R. (2013), Taxing Freedom in Thessalian Manumission Inscriptions. Leiden-Boston. 